Available online at http://journal.stkip-andi-matappa.ac.id/index.php/histogram/index

Histogram : Jurnal Pendidikan Matematika 4(1), 2020, 117 - 127

\title{
PENGARUH IKLIM KELAS DAN KECERDASAN INTERPERSONAL TERHADAP HASIL BELAJAR
}

\author{
Irmawaty Natsir ${ }^{1 *}$, Anis Munfarikhatin ${ }^{2}$ \\ 1, 2 Universitas Musamus Merauke \\ * Corresponding Author. Email: natsir_fkip@unmus.ac.id \\ Received: 08 Maret 2020; Revised: 24 Maret 2020; Accepted: 30 Maret 2020
}

\begin{abstract}
ABSTRAK
Penelitian ini adalah penelitian ex-post facto yang bertujuan untuk mengetahui hubungan antara iklim kelas, kecerdasan interpersonal dan hasil belajar matematika. Populasi dalam penelitian ini adalah seluruh siswa kelas VII SMP Negeri di Kecamatan Biringkanaya Kota Makassar sebanyak 2818 siswa dengan jumlah sampel 236 siswa. Teknik pengambilan sampel dalam penelitian ini menggunakan two-stage proporsional stratified random sampling. Instrumen yang digunakan yakni: Skala iklim kelas, Skala kecerdasan interpersonal, dan Tes hasil belajar matematika. Data dianalisis dengan statistika deskriptif dan analisis SEM (Structure Equation Modelling). Hasil penelitian menunjukkan bahwa: (1) Variabel iklim kelas berada dalam kategori "sedang", variabel kecerdasan interpersonal berada dalam kategori "tinggi" dan variabel hasil belajar matematika berada dalam kategori "sedang”; (2) Terdapat hubungan yang positif dan signifikan antara iklim kelas dengan kecerdasan interpersonal; (3) Iklim kelas secara langsung berpengaruh positif terhadap hasil belajar matematika dengan besar pengaruh 19\%; (4) Kecerdasan interpersonal secara langsung berpengaruh positif terhadap hasil belajar matematika dengan besar pengaruh $25 \%$.
\end{abstract}

Kata Kunci: iklim kelas, interpersonal, hasil belajar

\begin{abstract}
This research is an ex-post facto research that aims to understand the relationship between class climate, interpersonal intelligence and mathematics learning outcomes. The population in this study were all students of class VII State Junior High School in Biringkanaya District Makassar City as many as 2818 students with a sample of 236 students. The sampling technique in this study uses two-stage proportional stratified random sampling. The instruments used are: class sensitive scale, interpersonal intelligence scale, and mathematics learning achievement test. Data were analyzed with descriptive statistics and SEM (Structure Equation Modeling) analysis. The results showed that: (1) Class climate variables are in the "medium" category, interpersonal intelligence variables are in the "high" category and mathematics learning outcome variables are in the "medium" category; (2) There is a positive and significant relationship between class climate influence and interpersonal intelligence;(3) Class climate directly towards learning 19\%; (4) Interpersonal intelligence directly directs positive towards mathematics learning outcomes with a large influence of $25 \%$.
\end{abstract}

Keywords: class climate, interpersonal, learning outcomes

How to Cite: Natsir, D, \& Munfarikhatin, A. (2020). Pengaruh Iklim Kelas dan Kecerdasan Interpersonal terhadap Hasil Belajar. Histogram: Jurnal Pendidikan Matematika, 4(1), 117 - 127 , doi: http://dx.doi.org/10.31100/histogram.v4i1.568

Permalink/DOI: http://dx.doi.org/10.31100/histogram.v4i1.568

\section{PENDAHULUAN}

Pendidikan yang dilaksanakan di Indonesia bertujuan untuk meningkatkan kualitas sumber daya manusia yang diawali dengan pengelolaan proses pembelajaran yang menjadi

Copyright $\odot$ 2020, THE AUTHOR (S). This article distributed under the CC-BY-SA-license.

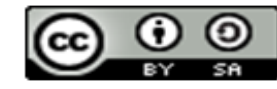




\section{Histogram: Jurnal Pendidikan Matematika, 4 (1), 2020 - 118 Irmawaty Natsir ${ }^{*}$, Anis Munfarikhatin ${ }^{2}$}

inti dari proses pendidikan secara keseluruhan. Salah satu tolak ukur keberhasilan siswa dalam belajar dapat dilihat dari hasil belajar siswa. Namun, rendahnya hasil belajar siswa kini menjadi masalah umum dalam dunia pendidikan di Negara kita saat ini, khususnya hasil belajar matematika.

Matematika merupakan salah satu mata pelajaran yang berperan dalam membentuk siswa menjadi berkualitas karena matematika sebagai sarana berpikir untuk mengkaji sesuatu secara logis, kritis, rasional dan sistematis serta melatih kemampuan siswa agar terbiasa dalam memecahkan suatu masalah yang ada disekitarnya, sehingga dapat mengembangkan kemampuan yang dimiliki oleh siswa. Namun dalam penerapannya, siswa menganggap matematika adalah polemik dan masalah yang harus dihindari, hal ini disebabkan karakteristik matematika yang bersifat abstrak sehingga membutuhkan penalaran dan kecerdasan (IQ) yang tinggi dalam penyelesaiannya.

Rendahnya hasil belajar matematika siswa dapat dipengaruhi oleh beberapa faktor, baik faktor internal maupun faktor eksternal. Faktor internal yang dapat mempengaruhi hasil belajar matematika antara lain: bakat, minat, kecerdasan, motivasi dan kemampuan kognitif. Dan, faktor eksternal yang dapat mempengaruhi hasil belajar matematika meliputi: lingkungan alam, lingkungan sosial, kurikulum, guru, sarana dan fasilitas. Iklim kelas merupakan bagian dari faktor eksternal yang menjadi salah satu faktor yang dapat mempengaruhi hasil belajar siswa. Iklim kelas yang kondusif membuat siswa merasa nyaman dalam mengikuti proses pembelajaran sehingga tujuan pembelajaran dapat tercapai. Sebaliknya, iklim kelas yang tidak kondusif akan berdampak negatif terhadap proses pembelajaran, siswa akan merasa gelisah, resah, bosan dan jenuh dalam belajar serta sulitnya tercapai tujuan pembelajaran. Dalam hal ini, tugas guru yang paling utama adalah mengkondisikan lingkungan belajar sehingga dapat menunjang terjadinya suatu perubahan perilaku bagi siswa karena masing-masing kelas memiliki lingkungan yang berbeda-beda dan unik, meskipun dibangun dalam struktur dan arsitektur yang sama.

Keberhasilan seorang guru di dalam kelas bukan hanya tercapainya suatu tujuan pembelajaran, tetapi seorang guru harus mampu menciptakan suasana belajar yang menyenangkan, komunikatif, menarik, dapat menumbuhkan kepercayaan diri siswa dan mengetahui perbedaan karakteristik yang dimiliki oleh siswa, sehingga proses pembelajaran dapat berlangsung dengan baik dan terarah yang akhirnya dapat meningkatkan hasil belajar siswa. Faktor lain yang dapat mempengaruhi hasil belajar matematika selain iklim kelas yakni faktor kecerdasan. Kecerdasan dipandang sebagai kemampuan untuk bertindak secara rasional dan dapat melakukan penyesuaian terhadap 


\section{Histogram: Jurnal Pendidikan Matematika, 4 (1), 2020 - 119 Irmawaty Natsir ${ }^{*}$, Anis Munfarikhatin ${ }^{2}$}

berbagai aspek dari kehidupan individu. Dalam dunia pendidikan saat ini, kecerdasan yang dimiliki oleh siswa tidak hanya terbatas pada kemampuan yang dimiliki oleh siswa yang dapat diukur melalui tes IQ. Menurut Gardner (Ormrod, 2008) ada delapan jenis kecerdasan, yakni kecerdasan verbal linguistik, kecerdasan logika matematika, kecerdasan spasial, kecerdasan musik, kecerdasan kinestetik, kecerdasan interpersonal, kecerdasan intrapersonal dan kecerdasan naturalis. Dalam kaitannya dengan proses pembelajaran matematika, siswa dituntut untuk memiliki kemampuan berinteraksi dalam kelompok belajar maupun dalam lingkungan kelas. Kemampuan siswa berinteraksi dalam kelompok belajar maupun dalam lingkungan kelas dikenal sebagai kecerdasan interpersonal. Kecerdasan interpersonal merupakan kemampuan anak dalam memahami pikiran, sikap, perasaan dan perilaku orang lain serta dapat membangun kedekatan dan hubungan dengan orang lain. Menurut Gardner (Wahyudi, 2011) Kecerdasan interpersonal adalah kemampuan untuk mengamati, mengerti tujuan, motivasi dan perasaan orang lain, peka pada ekspresi wajah, suara dan gerakan tubuh orang lain dan mampu memberikan respon secara efektif dalam berkomunikasi. Kecerdasan ini juga mampu masuk ke dalam diri orang lain, mengerti dunia orang lain, mengerti pandangan dan sikap orang lain serta dapat memimpin kelompok. Kecerdasan Interpersonal juga sering disebut sebagai kecerdasan sosial, selain kemampuan menjalin persahabatan yang akrab dengan siswa, kecerdasan ini juga mencakup kemampuan dalam hal memimpin, mengorganisir, menangani perselisihan antarsiswa, memperoleh simpati dari siswa yang lain, dan sebagainya. Kecerdasan interpersonal menunjukkan kemampuan seseorang untuk peka terhadap perasaan orang lain dan dapat memahami serta berinteraksi dengan orang lain sehingga mudah bersosialisasi dengan lingkungan di sekelilingnya.

Berdasarkan informasi yang diperoleh bahwa rata-rata siswa memiliki kecerdasan (IQ) yang tinggi, tetapi tidak memiliki kecerdasan sosial yang baik hal ini terlihat dari sikap siswa yang tidak peduli dengan siswa yang lain, khususnya dalam belajar kelompok masih terlihat beberapa siswa yang mendominasi, tidak adanya kerjasama dalam menyelesaikan masalah yang diberikan oleh guru, dan masih terdapat siswa yang bersikap cuek, kurang senang dan terlihat terpaksa mengikuti proses pembelajaran, serta saat istirahat rata-rata siswa sibuk dengan handphone yang dimilikinya, walaupun sudah ada larangan tidak diperbolehkan membawa hanphone ke sekolah tetapi masih ada beberapa siswa yang tidak mematuhi aturan tersebut.

Lebih lanjut, siswa sekarang tumbuh dalam kesepian dan depresi, lebih mudah stress, lebih mudah marah, kasar, mudah terpengaruh dan cenderung sering cemas dan sulit 


\section{Histogram: Jurnal Pendidikan Matematika, 4 (1), 2020 - 120 \\ Irmawaty Natsir $^{1 *}$, Anis Munfarikhatin ${ }^{2}$}

beradaptasi dengan lingkungan sekitar. Diduga hal ini terjadi, karena suasana kelas yang tidak terkontrol dengan baik, kurangnya sikap saling menghargai antar siswa, kurangnya perhatian dari guru dan orang tua, masih adanya siswa yang bersikap egois, dan sulit diatur serta tidak adanya kewajiban guru untuk mengetahui secara khusus karakteristik kecerdasan yang dimiliki oleh siswanya. Pada umumnya guru hanya beranggapan bahwa siswa yang pandai secara akademik, secara otomatis memiliki kemampuan dalam berinteraksi dengan siswa yang lain dan warga sekolah, sehingga guru hanya mengelompokkan siswa berdasarkan tingkat kecerdasan (IQ).

Solusi dari masalah tersebut yakni guru harus menciptakan suasana belajar yang menyenangkan bagi siswa dalam kegiatan pembelajaran sehingga dapat meningkatkan hasil belajar matematika siswa. Dalam meningkatkan hasil belajar matematika siswa diperlukan iklim kelas yang kondusif sehingga siswa akan merasa nyaman ketika memasuki ruang kelas, mereka mengetahui bahwa akan ada yang memperdulikan dan menghargai mereka. Lebih lanjut, seorang guru harus mengetahui karakteristik kecerdasan yang dimiliki oleh siswanya, sehingga dapat menentukan model atau metode yang akan diterapkan pada proses pembelajaran.

\section{METODE PENELITIAN}

\section{A. Jenis Penelitian}

Penelitian ini merupakan penelitian ex-post facto yang bersifat kausalitas yang bertujuan menelusuri hubungan sebab akibat antar variabel. Penelitian ini terdiri dari variabel eksogen (sebab) yakni iklim kelas dan kecerdasan interpersonal dan variabel endogen (akibat) yakni hasil belajar matematika.

\section{B. Populasi dan Sampel}

Populasi dalam penelitian ini adalah seluruh siswa kelas VII SMP Negeri di Kecamatan Biringkanaya Kota Makassar tahun ajaran 2013/2014 sebanyak 9 sekolah dengan jumlah siswa 2818 siswa. Teknik pengambilan sampel yang digunakan yakni twostage proporsional stratified random sampling dengan jumlah sampel sebanyak 236 siswa.

\section{Instrumen Penelitian}

Instrumen yang digunakan dalam penelitian ini adalah tes (tes hasil belajar kognitif matematika) dan non tes (angket). Sebelum instrumen di uji cobakan, dilakukan uji validitas dan uji reliabilitas. Hasil uji validitas dan reliabilitas untuk skala iklim kelas diperoleh hasil item yang konsisten sebanyak 24 item dan item yang gugur sebanyak 11 dari 35 item yang telah di uji cobakan di SMP Negeri 9 Makassar. Nilai koefisien korelasi item total pada uji coba instrumen sebanyak 35 item berada antara $-0,28$ sampai dengan 


\section{Histogram: Jurnal Pendidikan Matematika, 4 (1), 2020 - 121 Irmawaty Natsir ${ }^{*}$, Anis Munfarikhatin ${ }^{2}$}

0,563 dengan nilai Cronbach's Alpha's sebesar 0,79 atau 79\%. Setelah menganalisis kembali dengan membuang 11 item yang tidak konsisten, maka koefisien korelasi item total berada antara 0,26 sampai dengan 0,62 dengan nilai Cronbach's Alpha sebesar 0,84 atau 84\% mengalami kenaikan pada koefisien korelasi dan Cronbach's Alpha. Setelah melihat kekonsistenan internal item dan analisis penskalaan iklim kelas serta pertimbangan keefisienan waktu, maka terdapat 20 item yang gugur sehingga jumlah item yang dipakai dalam penelitian ini sebanyak 15 item.

Selajutnya, hasil uji validitas dan reliabilitas untuk skala kecerdasan interpersonal diperoleh hasil item yang konsisten sebanyak 20 item dan item yang gugur sebanyak 12 dari 32 item yang telah di uji cobakan di SMP Negeri 9 Makassar. Nilai koefisien korelasi item total pada uji coba instrumen sebanyak 32 item berada antara -0,22 sampai dengan 0,69 dengan nilai Cronbach's Alpha's sebesar 0,79 atau 79\%. Setelah menganalisis kembali dengan membuang 12 item yang tidak konsisten, maka koefisien korelasi item total berada antara 0,19 sampai dengan 0,73 dengan nilai Cronbach's Alpha sebesar 0,88 atau $88 \%$ mengalami kenaikan pada koefisien korelasi dan Cronbach's Alpha. Setelah melihat kekonsistenan internal item dan analisis penskalaan kecerdasan interpersonal serta pertimbangan keefisienan waktu, maka terdapat 20 item yang gugur sehingga jumlah item yang dipakai dalam penelitian ini adalah sebanyak 12 item. Dan, untuk hasil uji validitas dan reliabilitas tes hasil belajar diperoleh hasil item yang konsisten sebanyak 20 item dan item yang gugur sebanyak 15 dari 35 item yang telah di uji cobakan di SMP Negeri 9 Makasssar. Nilai koefisien korelasi item total pada uji coba instrumen sebanyak 35 item pertanyaan berada antara -0,34 sampai dengan 0,82 dengan nilai Cronbach's Alpha's sebesar 0,81 atau $81 \%$. Setelah dianalisis kembali dengan membuang 15 item yang tidak konsisten, maka koefisien korelasi item total berada antara 0,24 sampai dengan 0,87 dengan nilai Cronbach's Alpha sebesar 0,92 atau 92\% mengalami kenaikan pada koefisien korelasi dan Cronbach's Alpha. Setelah melihat kekonsistenan internal item dan pertimbangan keefisienan waktu, maka terdapat 15 item yang gugur sehingga jumlah item pertanyaan yang dipakai dalam penelitian ini adalah sebanyak 20 item.

Berdasarkan uji validitas dan uji reliabilitas maka pengumpulan data dalam penelitian ini untuk tes hasil belajar matematika terdiri dari 20 butir soal pilihan ganda, dan pengumpulan data untuk skala iklim kelas terdiri dari 15 pernyataan dan skala kecerdasan interpersonal terdiri dari 12 pernyataan.

\section{Teknik Analisis Data}




\section{Histogram: Jurnal Pendidikan Matematika, 4 (1), 2020 - 122 \\ Irmawaty Natsir $^{1 *}$, Anis Munfarikhatin ${ }^{2}$}

Analisis data terdiri dari dua tahap, tahap pertama analisis data untuk butir pernyataan-pernyataan dalam instrumen, tahap kedua analisis data untuk menjawab masalah penelitian. Teknik analisis data yang digunakan adalah statistik deskriptif dan inferensial. Statistik deskriptif untuk mendeskripsikan data dari variabel-variabel penelitian yang meliputi mean, median, variansi, skewness, kurtosis, minimum, maksimum, dan analisis presentase. Dan Statistik inferensial digunakan untuk analisis dan validasi model yang diusulkan serta pengujian hipotesis. Oleh karena itu, digunakan teknik analisis SEM dengan menggunakan program AMOS (Analysis Of Moment Structure) dan SPSS IBM versi 20.0 .

\section{HASIL DAN PEMBAHASAN}

\section{A. Hasil Penelitian}

Berdasarkan hasil penelitian menunjukkan bahwa iklim kelas siswa kelas VII SMP Negeri di Kecamatan Biringkanaya Kota Makassar berada dalam kategori sedang dengan persentase sebesar $67 \%$ dan skor rata-rata 50,65 yang terdiri dari: 4 siswa yang iklim kelasnya berada dalam kategori sangat rendah, 43 siswa yang iklim kelasnya berada dalam kategori rendah, 65 siswa yang iklim kelasnya berada dalam kategori sedang, 75 siswa yang iklim kelasnya berada dalam kategori tinggi, dan 49 siswa yang iklim kelasnya berada dalam kategori sangat tinggi. Data ini memberikan gambaran bahwa iklim kelas siswa kelas VII SMP Negeri di Kecamatan Biringkanaya Kota Makassar sudah cukup kondusif. Iklim kelas yang kondusif akan memberikan kenyamanan kepada siswa untuk tetap berada di dalam kelas dan senang mengikuti kegiatan pembelajaran, serta mampu meningkatkan rasa percaya diri siswa dalam pembelajaran.

Lebih lanjut, kecerdasan interpersonal pada siswa kelas VII SMP Negeri di Kecamatan Biringkanaya Kota Makassar berada dalam kategori tinggi dengan persentase sebesar 76\% dan skor rata-rata 45,54 yang terdiri dari: tidak ada siswa yang keceradasan interpersonalnya berada dalam kategori sangat rendah, 5 siswa memiliki kecerdasan interpersonal yang berada dalam kategori rendah, 33 siswa memiliki kecerdasan interpersonal yang berada dalam kategori sedang, 126 siswa memiliki keceradasan interpersonal yang berada dalam kategori tinggi, dan 72 siswa lainnya memiliki kecerdasan interpersonal yang berada dalam kategori sangat tinggi. Data ini memberikan gambaran bahwa siswa kelas VII SMP Negeri di Kecamatan Biringkanaya Kota Makassar sudah mampu dalam membangun kecerdasan interpersonalnya dengan baik, sehingga memiliki kemampuan dalam berhubungan dengan orang lain, mampu menjalankan komunikasi yang efektif dengan orang lain, mampu berempati secara baik, mampu mengembangkan 


\section{Histogram: Jurnal Pendidikan Matematika, 4 (1), 2020 - 123 \\ Irmawaty Natsir $^{1 *}$, Anis Munfarikhatin ${ }^{2}$}

hubungan yang harmonis dengan orang lain, dan dapat dengan cepat memahami tempramen, sifat dan kepribadian orang lain. Dengan keceradasan interpersonal yang dimilikinya, akan membuat mereka lebih berhasil dalam dunia sosialnya.

Dan, hasil belajar matematika pada siswa kelas VII SMP Negeri di Kecamatan Biringkanaya Kota Makassar berada dalam kategori sedang dengan skor rata-rata 65,78 yang terdiri dari:14 siswa berada dalam kategori sangat rendah, 79 siswa berada dalam kategori rendah, 88 berada dalam kategori sedang, 50 siswa berada dalam kategori tinggi, dan 7 orang lainnya berada dalam kategori sangat tinggi. Data ini memberikan gambaran bahwa hasil belajar matematika siswa kelas VII SMP Negeri di Kecamatan Biringkanaya Kota Makassar cukup baik, walaupun masih terdapat beberapa siswa yang lupa dengan materi, kurang percaya diri dengan jawaban yang dimilikinya sehingga cenderung meniru jawaban siswa yang lain.

Selanjutnya, pengujian hipotesis penelitian mengenai hubungan iklim kelas dan kecerdasan interpersonal, pengaruh iklim kelas dan kecerdasan interpersonal terhadap hasil belajar matematika serta besar sumbangan efektif dari tiap variabel yang dapat dilihat pada tabel berikut.

Tabel 1. Korelasi $X_{1}$ dan $X_{2}$

\begin{tabular}{llll}
\hline & & & Estimate \\
\hline Kecedasan & $<->$ & Iklim & 0,44 \\
Interpersonal & & Kelas & \\
\hline
\end{tabular}

(Sumber: Data Primer, Tahun: 2014)

Tabel 2. Hasil Estimasi Kooefisian Regresi Persamaan Struktural untuk Model Fit

\begin{tabular}{|c|c|c|c|c|c|c|c|}
\hline & & & $\begin{array}{l}\text { S.Regre } \\
\text { sion } \\
\text { weigth } \\
\end{array}$ & Estimate & S.E. & C.R. & $\mathbf{P}$ \\
\hline $\begin{array}{l}\mathrm{HB} \\
\text { matematika }\end{array}$ & $<--$ & Iklim kelas & 0,29 & 0,08 & 0,03 & 2,89 & 0,00 \\
\hline $\begin{array}{l}\mathrm{HB} \\
\text { matematika }\end{array}$ & $<---$ & $\begin{array}{l}\text { Kecerdasan } \\
\text { interperson } \\
\text { al }\end{array}$ & 0,38 & 0,22 & 0,09 & 2,28 & 0,02 \\
\hline $\begin{array}{l}\text { Kecerdasan } \\
\text { interpersonal }\end{array}$ & $\langle-->$ & Iklim kelas & 0,44 & 1,72 & 0,41 & 4,26 & $<0,00$ \\
\hline
\end{tabular}

(Sumber: Data Primer, Tahun: 2014)

Tabel 3. Sumbangan Efektif Variabel X terhadap Variabel Y

\begin{tabular}{cccc}
\hline No & Pengaruh $\mathbf{X}$ terhadap $\mathbf{Y}$ & Langsung & Total \\
\hline 1 & $\mathrm{X}_{1}$ & 0,19 & 0,19 \\
\hline
\end{tabular}




\section{Histogram: Jurnal Pendidikan Matematika, 4 (1), 2020 - 124 \\ Irmawaty Natsir ${ }^{*}$, Anis Munfarikhatin ${ }^{2}$}

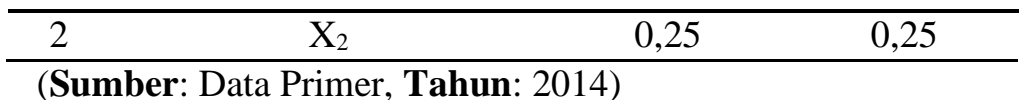

Berdasarkan hasil analisis statistik inferensial diperoleh bahwa: (1) terdapat hubungan yang positif dan signifikan antara iklim kelas dengan kecerdasan interpersonal dengan hasil estimasi $r_{12}=0,44$ dan nilai $p<0,00$. (2) terdapat pengaruh langsung yang positif dan signifikan dari iklim kelas $\left(\mathrm{X}_{1}\right)$ terhadap hasil belajar matematika $(\mathrm{Y})$ pada taraf signifikan 0,05 dengan hasil estimasi $\widehat{\gamma_{21}}=0,29$ dan nilai $p=0,00<0,05$ serta sumbangan efektif sebesar 19\%. (3) terdapat pengaruh langsung yang positif dan signifikan dari kecerdasan interpersonal $\left(\mathrm{X}_{2}\right)$ terhadap hasil belajar matematika $(\mathrm{Y})$ pada taraf signifikan 0,05 dengan hasil estimasi $\widehat{\gamma_{22}}=0,38$ dan nilai $p=0,02<0,05$ serta sumbangan efektif sebesar $25 \%$.

\section{b. Pembahasan}

Berdasarkan hasil pengujian hipotesis yang pertama menunjukkan bahwa ada hubungan yang positif dan signifikan antara iklim kelas dengan kecerdasan interpersonal. Hasil penelitian ini sejalan dengan pendapat Freiberg dan Stein (Muijs, Daniel \& Reynolds, 2008) yang mengemukakan bahwa iklim kelas mencakup mood (suasana perasaan) atau atmosfer yang diciptakan oleh guru di dalam kelas melalui aturan-aturan yang ditetapkan, cara guru berinteraksi dengan siswa, dan bagaimana lingkungan fisik dikelola. Iklim kelas ditandai dengan munculnya sikap saling terbuka antara guru dengan siswa, siswa dengan siswa, siswa dengan warga sekolah, terjalinnya hubungan antar pribadi yang akrab, dan sikap saling menghargai satu dengan yang lain, serta saling menghormati satu sama lain. Iklim kelas yang tidak kondusif akan berdampak negatif terhadap proses pembelajaran. Dimana dalam proses pembelajaran siswa dituntut harus melibatkan interaksi yang baik antara siswa dengan guru, guru dengan siswa, dan siswa dengan siswa serta interaksi siswa dalam kelompok belajar di dalam kelas. Kemampuan siswa berinteraksi dikenal sebagai kecerdasan interpersonal seorang anak. Iklim kelas tidak terlepas dari hubungan antarpribadi (kecerdasan interpersonal). Menurut Gardner (Wahyudi, 2011) kecerdasan interpersonal merupakan kemampuan anak dalam menjalin hubungan dengan orang lain. Anak yang cerdas secara interpersonal memiliki kemampuan peka terhadap perasaan orang lain dan mampu memahami serta berinteraksi dengan orang lain sehingga mudah bersosialisasi dengan lingkungan di sekelilingnya. Iklim kelas dapat mempengaruhi kecerdasan interpersonal seorang anak begitu pula sebaliknya anak yang memiliki kecerdasan interpersonal yang kurang baik, maka dapat mempengaruhi lingkungan kelas dimana anak itu berada. 


\section{Histogram: Jurnal Pendidikan Matematika, 4 (1), 2020 - 125 Irmawaty Natsir ${ }^{*}$, Anis Munfarikhatin ${ }^{2}$}

Berdasarkan hasil pengujian hipotesis yang kedua menunjukkan bahwa iklim kelas berpengaruh positif dan signifikan dengan hasil belajar matematika dengan besar sumbangan efektif $19 \%$. Hasil penelitian ini sejalan dengan penelitian yang dilakukan oleh (Bennett, 2001), hasil yang diperoleh pada penelitian yang dilakukan Bennet salah satunya adalah iklim kelas memiliki pengaruh terhadap prestasi belajar/ hasil belajar siswa, meskipun tidak terlalu besar. Sejalan dengan Bennet, (Admoko, 2009) mengungkapkan dalam penelitiannya terdapat pengaruh positif dan signifikan iklim kelas terhadap prestasi belajar akuntansi. Dan, penelitian yang dilakukan Walberg \& Greenberg (Porter, 2000) menunjukkan bahwa lingkungan sosial atau suasana kelas adalah penentu psikologis utama yang mempengaruhi belajar akademis, lebih lanjut Walberg (Tarmidi \& Wulandari, 2005) menyatakan bahwa kejadian-kejadian dan kondisi dalam lingkungan sosial (suasana kelas) dan persepsi pelajar terhadap iklim belajar sangat signifikan dalam memprediksi prestasi. Hal tersebut senada dengan pernyataan Fraser (Yates, 2001) yang menyatakan bahwa iklim kelas dapat mempengaruhi pembelajaran siswa. Menurut, Bloom (Tarmidi \& Wulandari, 2005) iklim kelas adalah kondisi, pengaruh, dan rangsangan dari luar yang meliputi pengaruh fisik, sosial dan intelektual yang mempengaruhi siswa. Iklim kelas yang kondusif untuk belajar akan menyebabkan siswa merasa senang dengan kegiatan pembelajaran yang dia ikuti, mampu meningkatkan rasa percaya diri siswa, mampu menyelesaikan masalahmasalah yang diberikan, dan dapat bersosialisasi dengan baik di lingkungan kelasnya. Hal ini berarti, apabila siswa belajar pada suatu iklim kelas yang kondusif, maka siswa akan berusaha mencapai hasil belajar yang baik. Hal yang sama juga diungkapkan oleh Walker (Hadinata, 2009) bahwa ketika siswa merasa sebagai bagian dalam kelompok belajar maka mereka akan memperlihatkan perilaku prososial, mengerjakan tugas, antusias terhadap aktivitas-aktivitas kelas dan menunjukkan prestasi yang tinggi.

Berdasarkan hasil pengujian hipotesis yang ketiga menunjukkan bahwa kecerdasan interpersonal berpengaruh positif dan signifikan dengan hasil belajar matematika dengan besar sumbangan efektif $25 \%$. Hasil penelitian ini sejalan dengan penelitian yang dilakukan oleh (Azis \& Joharman, 2013), yang mengemukakan bahwa kecerdasan interpersonal siswa berpengaruh sangat signifikan terhadap prestasi belajar siswa. Lebih lanjut, (Sholihah \& Karyanto, 2012) mengungkapkan dalam penelitiannya bahwa terdapat hubungan yang positif dan signifikan antara kecerdasan interpersonal terhadap hasil belajar kognitif biologi. (Tobing, 2013) juga mengemukakan hal yang sama dengan Sholihah, yang mengemukakan bahwa terdapat hubungan yang signifikan antara kecerdasan interpersonal dengan hasil belajar biologi siswa kelas XI IPA SMA Negeri 1 Dolok Merawan tahun 


\section{Histogram: Jurnal Pendidikan Matematika, 4 (1), 2020 - 126 \\ Irmawaty Natsir ${ }^{1 *}$, Anis Munfarikhatin ${ }^{2}$}

pelajaran 2013/2014. Semakin tinggi kecerdasan interpersonal yang dimilki oleh seorang anak, maka semakin tinggi pula kecenderungan anak tersebut untuk memiliki hasil belajar yang tinggi, sebaliknya semakin rendah kecerdasan interpersonal yang dimiliki oleh seorang anak maka semakin rendah pula kecenderungan anak tersebut memiliki hasil belajar yang rendah. Hal ini, sejalan dengan hasil penelitian yang dilakukan oleh (Nurwati, 2009) yang menemukan bahwa semakin baik interaksi antara siswa dengan guru, siswa dengan siswa, maka hasil belajarnya semakin tinggi. Kecerdasan interpersonal memiliki arti penting dalam mencapai hasil belajar yang optimal, dengan kemampuan interpersonal yang dimiliki oleh seorang anak, akan memberikan kenyamanan dan dapat menunjang kerjasama sehingga menumbuhkan motivasi dan mengoptimalkan hasil belajarnya.

\section{KESIMPULAN DAN SARAN}

\section{A. Kesimpulan}

Kesimpulan dalam penelitian ini adalah: variabel iklim kelas berada dalam kategori sedang dengan skor rata-rata 50,65 dan persentase sebesar 67\%, variabel kecerdasan interpersonal berada dalam kategori tinggi dengan skor rata-rata 45,53 dan persentase sebesar $76 \%$ dan variabel hasil belajar matematika berada dalam kategori sedang dengan skor rata-rata 65,78. Terdapat hubungan yang positif antara iklim kelas dengan kecerdasn interpersonal siswa kelas VII SMP Negeri di Kecamatan Biringkanaya Kota Makassar; Iklim kelas berpengaruh positif dan signifikan terhadap hasil belajar matematika dengan besar sumbangan efektif 19\%; Kecerdasan interpersonal berpengaruh positif dan signifikan terhadap hasil belajar matematika dengan besar sumbangan efektif $25 \%$.

\section{B. Saran}

Adapun saran dalam penelitian ini adalah: dapat menjadi acuan guru dalam melihat faktor-faktor yang dapat mempengaruhi hasil belajar siswa khususnya hasil belajar matematika, dan guru dapat memahami karakteristik kecerdasan yang dimiliki oleh siswanya sehingga dapat menentukan metode atau model yang tepat diterapkan dalam proses pembelajaran.

\section{DAFTAR PUSTAKA}

Admoko, D. (2009). Pengaruh Disiplin Belajar, Iklim Kelas dan Persepsi Siswa tentang Kompetensi Guru terhadap Prestasi Belajar Akintansi Studi Kasus pada Siswa Kelas XI IPS SMA Negeri 1 Cangkringan. Yogyakarta: Skripsi Universitas Sanata Dharma.

Azis, K., \& Joharman, S, K. (2013). Hubungan antara Kecerdasan Interpersonal, Berpikir 


\section{Histogram: Jurnal Pendidikan Matematika, 4 (1), 2020 - 127 \\ Irmawaty Natsir $^{1 *}$, Anis Munfarikhatin ${ }^{2}$}

Kreatif dan Hasil Menulis Kelas V SD Negeri di Kabupaten Kebumen. Kalam Cendikia PGSD Kebumen, 1(3), 1-3.

Bennett, J. (2001). The Relationship Between Classroom Climate and Student Achievement. In Dissertation. University Of North Texas.

Hadinata, P. (2009). Iklim Kelas dan Motivasi Belajar Siswa SMA. Jurnal Psikologi, 3(1), 93-98.

Muijs, Daniel \& Reynolds, D. (2008). Effective Teaching Teori dan Aplikasi, Edisi Kedua. Yogyakarta: Pustaka Pelajar.

Nurwati. (2009). Hubungan Antara Interaksi Sosial Siswa dengan Prestasi Belajar Bahasa Indonesia Siswa Madrasah Ibtidaiyah Se-Kabupaten Gorontalo. Cakrawala Pendidikan, XXVIII(2), 109-119.

Ormrod, J, E. (2008). Psikologi Pendidikan: Membantu Siswa Tumbuh dan Berkembang, Edisi keenam (Jilid I). Jakarta: Erlangga.

Porter, D. (2000). Quantum Teaching Menpraktikkan Quantum Learning di Ruang-Ruang Kelas. Bandung: Kaifa.

Sholihah, I, M \& Karyanto, P. (2012). Kekuatan dan Arah Kemampuan Metakognisi, Kecerdasan Verbal, dan Kecerdasan Interpersonal Hubungannya dengan Hasil Belajar Biologi Siswa XI IPA SMA Negeri 3 Sukoharjo. Jurnal Pendidikan Biologi, 4(1), 31-39.

Tarmidi \& Wulandari, L. (2005). Prestasi Belajar Ditinjau dari Persepsi Siswa Terhadap Iklim Kelas pada Siswa yang Mengikuti Program Percepatan Belajar. Jurnal Psikologi, 1(1), 19-27.

Tobing, E, J, S, L. (2013). Hubungan Intelegensi Interpersonal dengan Hasil Belajar Biologi kelas XI IPA SMA Negeri 1 Dolok Merawan Tahun Pembelajaran 2013/2014. Medan: Skripsi Universitas Negeri Medan

Wahyudi, D. (2011). Pembelajaran IPS Berbasis Kecerdasan Intrapersonal, Interpersonal, dan Eksistensial. Jurnal UPI, Edisi Khusus(1), 33-45.

Yates, S, M. (2001). Student's Achievement and Perception of School Climate During the Transition from Single Sex Eduacation to Co-education. International Education Journal, 2(4), 317-328. 